\title{
The early stages and life histories of three Eumerus and two Merodon species (Diptera: Syrphidae) from the Mediterranean region
}

\author{
Antonio Ricarte, M. Ángeles Marcos-García \& Graham E. Rotheray
}

\begin{abstract}
Ricarte, A., Marcos-García, Á. \& Rotheray, G. E. 2008: The early stages and life histories of three Eumerus and two Merodon species (Diptera: Syrphidae) from the Mediterranean region. — Entomol. Fennica 19: 129-141.

This paper describes the early stages and life histories of the syrphids Eumerus obliquus (Fabricius, 1805), E. pulchellus Loew, 1848, E. pusillus Loew, 1848, Merodon constans (Rossi, 1794) and M. luteihumerus Marcos-García, Vujić \& Mengual, 2007 (Diptera, Syrphidae) from Spain and Morocco. E. pulchellus, E. pusillus and M. luteihumerus were found inside bulbs of Urginea maritima (L.) Baker and E. pulchellus additionally in tubers of Asphodelus aestivus Brot. These data are some of the few obtained of natural plant relationships in these speciesrich genera. E. obliquus was found in fruits and platyclades of Opuntia maxima Mill., both insect and host plant are introductions. M. constans was found in commercially grown bulbs of Muscari comosum (L.) Mill. The Eumerus larvae studied here appear to more saprophagous than phytophagous but $M$. luteihumerus at least, seems to be a strict phytophage.
\end{abstract}

A. Ricarte \& M. A. Marcos-García, Instituto de Investigación de la Biodiversidad (CIBIO), Universidad de Alicante, E-03080 Alicante, Spain; E-mail: antonio.ricarte@ua.es,marcos@ua.es

G. E. Rotheray, National Museums of Scotland, National Museums Collection Centre, 242 West Granton Road, Edinburgh EH5 1JA; E-mail: g.rotheray (a)nms.ac.uk

Received 23 January 2007, accepted 22 August 2007

\section{Introduction}

The Mediterranean region is one of 18 world biodiversity hotspots (Blondel \& Aronson 1999). In many places the ground flora is typified by Amaryllidaceae, Asphodelaceae and Hyacinthaceae the species of which use underground storage organs such as bulbs and tubers to overcome adverse conditions (Farràs 1988). Associated with these plants are two syrphid genera, Eumerus Meigen, 1822 and Merodon Meigen, 1803 (Diptera, Syrphidae) that are the most species- rich in the Mediterranean region. Adults take pollen and nectar from the flowers. Some of the studied species, and probably many more that have yet to be reared, breed in the bulbs and tubers of the above mentioned plant families.

Eumerus is one of the largest syrphid genera in the Palaearctic region with 140 species (Peck 1988) and Merodon the second largest genus in Europe with more than 50 species. But the taxonomy of both genera is in need of revision (Speight 2006, Marcos-García et al. 2007). Both genera contain a few species that sometimes cause prob- 
lems for horticulture and agriculture (PérezBañón \& Marcos-García 1998) and there is an extensive literature about infestations and their control (Assem et al. 1972, Conijn 1990). However, the biology of Eumerus and Merodon in natural situations is practically unknown.

This paper describes the early stages and life histories of two species of Eumerus and one species of Merodon from the Mediterranean region and found breeding inside bulbs and tubers of Liliaceae sensu lato in natural conditions. Additionally we describe the early stages and life histories of Eumerus obliquus (Fabricius, 1805) and Merodon constans (Rossi, 1794) found breeding respectively, in platyclades of introduced cacti (Cactaceae) in Spanish Mediterranean islands and commercially grown bulbs (Liliaceae s.l.) from Morocco. Before this work, M. constans valid species (Vujić pers. com., Thompson 2006) was known only from Europe (Peck 1988) and $E$. obliquus was not cited in the Balearic Islands.

\section{Material and methods}

Eumerus and Merodon larvae were obtained from bulbs of Urginea maritima (L.) Baker (Hyacinthaceae) during fieldwork from 20042006 at Cabañeros National Park, (39 $23^{\prime} \mathrm{N}$; $4^{\circ} 29^{\prime} \mathrm{E}$ ) which is situated in the north-west of Ciudad Real province in the centre of Spain. Soil surrounding bulbs was removed with a trowel or knife and the bulb examined for signs of larval feeding, usually tunnels or discoloured tissues. Infested bulbs were removed and larvae reared in situ.

From Mallorca Island, Spain, (Palma de Mallorca: 39³4'N; 2³9'E), Eumerus larvae were obtained in 2005 from tubers of Asphodelus aestivus Brot. (Asphodelaceae) and decaying platyclades of Opuntia maxima Mill. (Cactaceae). Infested platyclades were recognised by using a knife to cut into the tissues and if the platyclade was decayed to the extent that a brown liquid or brown, softened tissues were present then the platyclade was opened by peeling back the thick outer epidermis and searched for larvae.

Larvae of $M$. constans were preserved specimens borrowed from the Smithsonian Institution (SI), Washington D.C., USA. They originated from bulbs of commercially grown $\mathrm{Muscari} \mathrm{co-}$ mosum (L.) Mill. (Hyacinthaceae) from Morocco.

Descriptions of early stages are based on preserved specimens using binocular microscopy with details of the posterior respiratory process (prp) and the pupal spiracles confirmed using scanning electron microscopy (SEM). Drawings were made with a drawing tube attached to a binocular microscope. Measurements were made with an eyepiece micrometer attached to the binocular microscope. SEM's were made with a JEOL 840 scanning electron microscope operated at $20 \mathrm{kV}$. Larval and puparial lengths were measured on the ventral surface from the anterior margin of the prothorax to the anus which is on the anterior margin of the anal segment (Rotheray \& Gilbert 1999). Widths and heights were maxima. In Eumerus the length of the prp was not measurable due to the base being hidden within the fleshy sheath of the anal segment. Size comparisons between the prp of Eumerus species were made by expressing the longitudinal distance from the characteristic transverse ridge to the centre of the spiracular plate $(a)$ as a proportion of the width of the prp at the level of the ridge (b). In Merodon although the base of the prp is visible, it is very short and greater variation was found between species in the width and height of the prp. Size comparisons between the prp of Merodon species were made by expressing the dorso-ventral height at the base of the prp $(c)$ as a proportion of the width at the base (d).

Larvae were reared in environmental chambers at an average of $20^{\circ} \mathrm{C}, 65-85 \%$ humidity and in continuous dark conditions. Larvae were kept in plastic boxes, isolated or grouped, with fresh or decaying whole or sectioned plant materials. Boxes were checked daily for puparia. Puparia were removed and placed individually in $55 \mathrm{~mm}$ diameter, plastic Petri dishes and inspected daily until the adult emerged. Adults were identified using keys in Sack (1932), de Moor (1973), Vujić and Simić (1999) and Marcos-García et al. (2007). M. constans adults were previously identified by staff from the Smithsonian Institution, USA, and F. C. Thompson.

Third stage larvae selected for preservation were recognised by the presence of two discs of differentiated cuticle on the dorsal surface of the 
first abdominal segment (Hartley 1961). Larvae were fixed by placing in cold water and boiled gently for about 4 minutes and preserved in $70 \%$ alcohol.

Head skeletons were examined by removing them from the antero-ventral margin of the puparium from which an adult had emerged. Head skeletons were extracted with pins after soaking in a solution of $\mathrm{KOH}$ for up to 30 mins. For $M$. constans the head skeleton was dissected from preserved larvae. In this process, the front end of a larva was cut off and placed in a solution of hot $\mathrm{KOH}$ for 5-10 minutes. When the tissues were cleared, the head skeleton was removed using pins. Head skeletons were examined in glycerine or $70 \%$ alcohol and preserved in glycerine. Egg descriptions use the terminology of Chandler (1968). Larval and puparial descriptions use the terminology of Hartley (1961) and Rotheray (1993) and head skeleton terminology follows Hartley (1963), Roberts (1969) and Rotheray and Gilbert (1999).

Voucher specimens of adult and immature stages of all species except $M$. constans which were part of the collections of the Smithsonian Institution, USA, were deposited in the Entomological Collection of Alicante University (CEUA) and the National Museums of Scotland (Edinburgh).

\section{Results}

\subsection{Descriptions of Eumerus puparia}

\subsubsection{Characters shared by Eumerus puparia}

Puparia oval in cross-section, tapered anteriorly, anal segment elongate; head: antennae and maxillary organs on a pair of rounded not cyclindrical projections; dorsal lip coated in setae; head skeleton: mouth-hooks external to the mouth, compared with Merodon, mandibles smaller and not as heavily sclerotised; mandibular lobes fleshy and attached to the mandibles; thorax: anterior spiracular process with spiracular openings at the apex of a short, cyclindrical, sclerotised projection; mesothoracic prolegs bearing crochets absent, except for E. obliquus; abdomen: locomotory organs usually present;

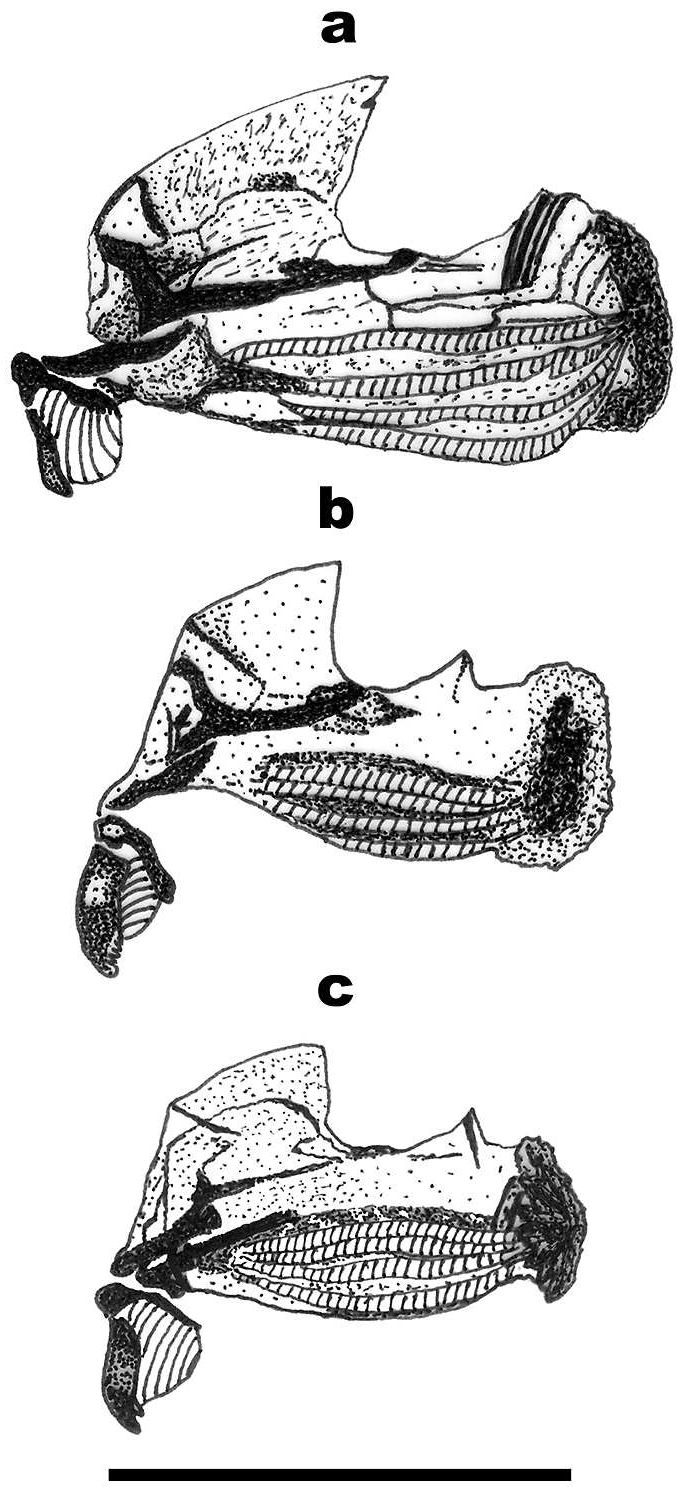

Fig. 1. Head skeletons of Eumerus species in lateral view (scale line $=1 \mathrm{~mm}$ ). - a. E. obliquus. - b. E. $p u$ sillus. - c. E. pulchellus.

prolegs with crochets only present in E. obliquus; anal segment elongate to varying degrees and bearing 4 instead of the usual 3 pairs of lappets (fleshy projections on the anal segment bearing sensilla (Rotheray \& Gilbert 1999), the middle pair divided into two approximated lappets; pupal spiracles with irregularly-spaced tubercles bearing openings; posterior respiratory process (prp): elongate, longer than apically broad; shiny, red- 

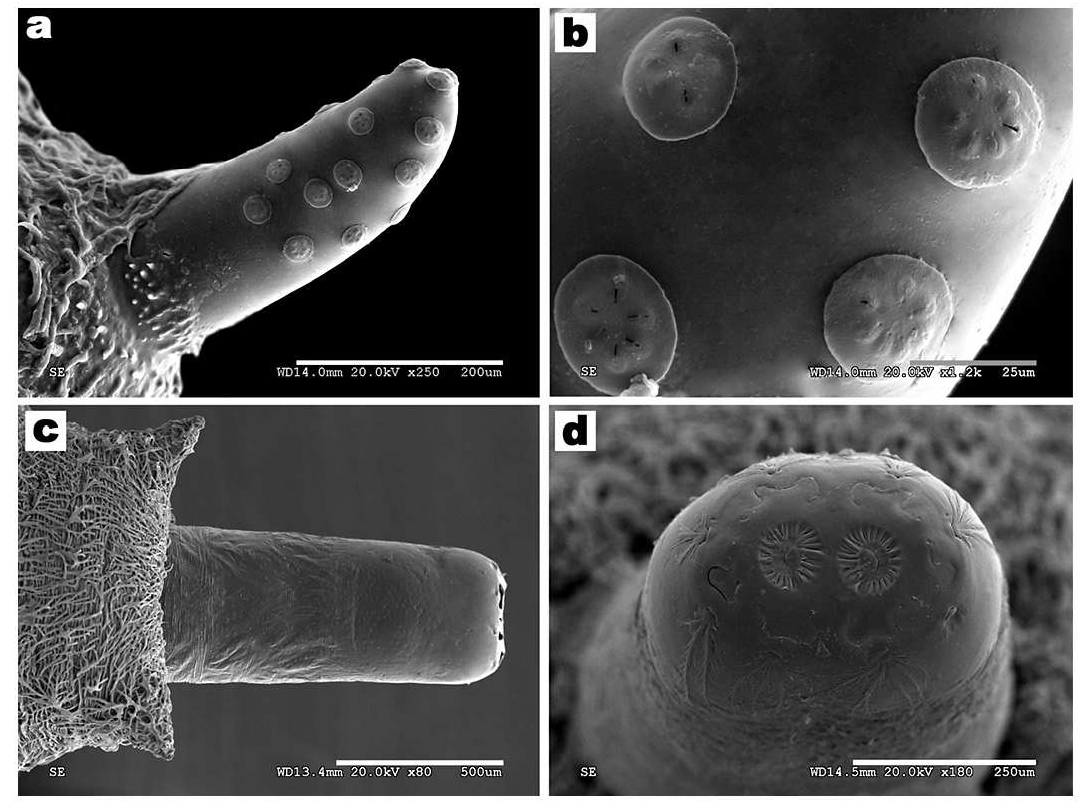

Fig. 2. E. obliquus, SEM "(scale and other photo data are shown at the bottom of each SEM). - a. Pupal spiracle in dorso-lateral view (scale line $=200 \mu \mathrm{m}$ ). -b. Details of spira-

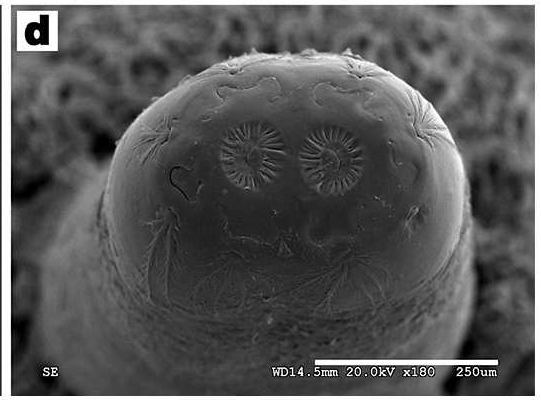
cular openings on pupal spiracle (scale line $=25 \mu \mathrm{m}) .-$ c. Posterior respiratory processes (prp) in dorsal view (scale line $=500 \mu \mathrm{m}$ ). -d. Prp showing the spiracular plate and setae in polar view (scale line $=250 \mu \mathrm{m})$.

brown in colour, transverse ridge weakly indicated; spiracular plates with 3 pairs of curved, spiracular openings.

\subsubsection{Eumerus obliquus (Fabricius, 1805)}

Puparium. Dimensions: length: mean $8.91 \mathrm{~mm}$ (range 7.1-10.1); width: mean $3.73 \mathrm{~mm}$ (range 2.86-4.1) $(n=10)$; head skeleton (Fig. 1a): mandibles not heavily sclerotised, 0.03 wide at midpoint in profile view; mandibular apodeme serrated apically; dorsal cornu tapering posteriorly in profile view; thorax: anterior respiratory process $0.09 \mathrm{~mm}$ long by $0.05 \mathrm{~mm}$ width, cylindrical in shape and yellowish-brown in colour; apex with a row of $4-5$ openings; mesothoracic prolegs present with two rows of 5-8 crochets; abdomen: first abdominal segment with pupal spiracles (Figs. 2a, b) about $0.6 \mathrm{~mm}$ long, separated by 5-6 times their length, bearing on the dorsal margin irregularly-spaced, oval-shaped tubercles; each tubercle with 5-7 spiracular openings, arranged radially; surface between tubercles smooth; prolegs present on the first 7 abdominal segments bearing 2 parallel rows of crochets; prp (Figs. 2c, d): length between the transverse ridge and the centre of the spiracular plate $(a)$ : mean $0.56 \mathrm{~mm}$ (range 0.42-0.71); width at the level of the ridge (b): mean $0.48 \mathrm{~mm}$ (range $0.42-0.54$ ); $a / b=1.16$ $(n=10)$; below ridge sculpture of faint striations and immediately above ridge, finely punctured then smooth at apex; spiracular openings sinuous in shape.

Biology. Larvae were found in wet, decaying platyclades of Opuntia maxima in November 2005. Each infested platyclade, lying on the ground or in the live plant, contained up to 70 larvae. Larvae also found in decaying fruits of $O$. maxima together with larvae of Myathropa florea (Linnaeus, 1758). Some puparia were found in old, dried platycades. Females were observed flying around the $O$. maxima plants.

Under controlled chamber conditions, larvae took up to 47 days to pupate and adults emerged after 7 to 24 days.

Material examined. Obtained from wet, decaying Opuntia maxima platyclades and fruits at various localities on Mallorca Island, Spain by M.A. Marcos-García and G. Rotheray, Ses Salines, 29.X.2005: 5 puparia and 18 larvae from which were reared 12 females and 9 males, 14.XI.-8.XII.2005; Porreres, 29.X.2005: 8 larvae from which were reared 5 females and 1 male 14.XI.-21.XII.2005; Banyalbufar, 29.X.2005: 5 larvae from which were reared 2 females and 3 males 21.X.-19.XII.2005; Villafranca de Bonany, 1.XI.2005: 2 puparia and 8 larvae from which were reared 5 females and 3 males 8.XI.- 
Fig. 3. E. pulchellus, SEM "(scale and other photo data are shown at the bottom of each SEM). - a. Pupal spiracle in dorso-lateral view (scale line $=100 \mu \mathrm{m}$ ). $-b$. Details of spiracular openings on pupal spiracle (scale line $=20 \mu \mathrm{m})$. - c. Posterior respiratory processes (prp) in dorsal view $($ scale line $=500 \mu \mathrm{m})$. d. Prp showing the spiracular plate and setae in polar view (scale line $=100 \mu \mathrm{m})$.
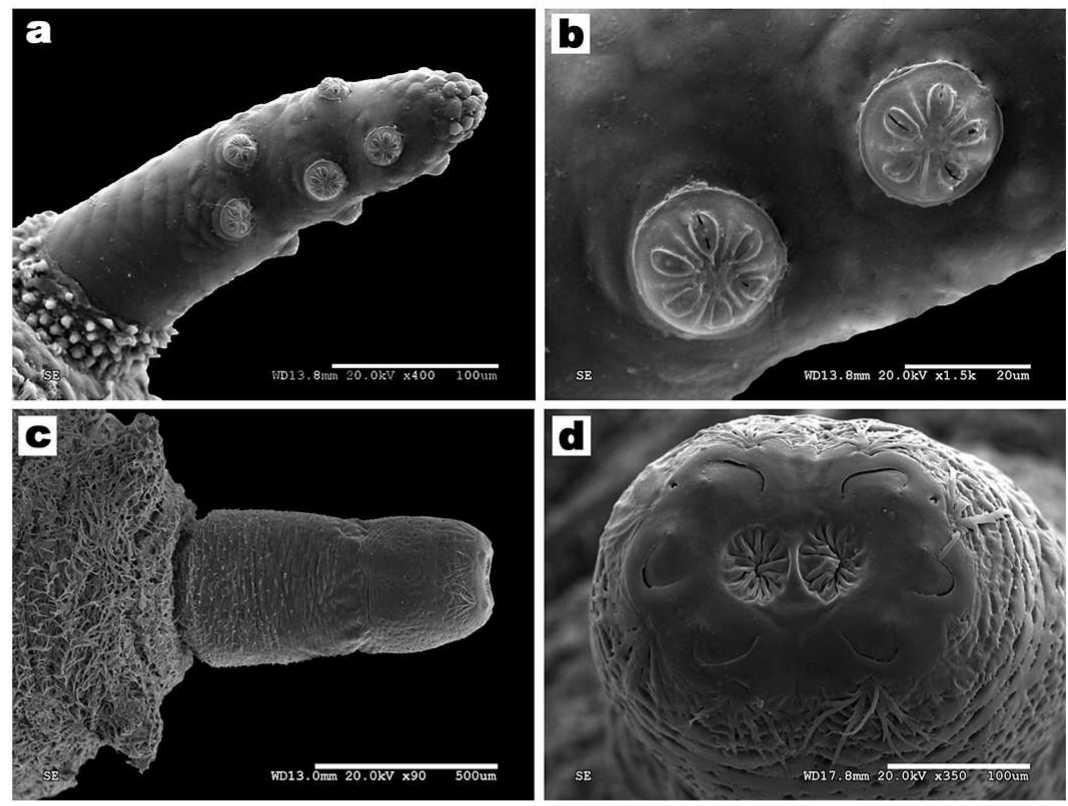

19.XII.2005; Baños de San Juan, 29.X.2005: 3 larvae from which were reared, 3 females on 30.XI.2005.

\subsubsection{Eumerus pulchellus Loew, 1848}

Puparium. Dimensions: length: $5.86 \mathrm{~mm}$ (5.716); width: $2.47 \mathrm{~mm}(2.38-2.56)(n=2)$; head skeleton (Fig. 1c): mandibles not heavily sclerotised and with an accessory tooth; mandible about twice as wide as E. obliquus; mandibular apodeme without serrations; thorax: anterior respiratory processes $0.1 \mathrm{~mm}$ long by $0.02 \mathrm{~mm}$ width, cylindrical in shape with 4-5 openings spread across the apex; mesothoracic prolegs absent; $a b-$ domen: pupal spiracles (Figs. 3a, b) $0.3 \mathrm{~mm}$ long, separated by a distance of $4 \times$ their length, with approximated tubercles at the apex; surface between tubercles with domed sculpture; each tubercle with $4-6$, radially arranged, oval openings, each opening separated by a line; locomotory organs slight with a single row of $2-3$ crochets on the first 6 abdominal segments; prp (Figs. 3c, d): length between the transverse ridge and the centre of the spiracular plate $(a): 0.63 \mathrm{~mm}(0.61-0.65)$; width at the level of the ridge $b: 0.34 \mathrm{~mm}(0.29$ $0.39) ; a / b=1(n=2)$; below transverse ridge transversally striated and above ridge finely punctured and sculptured at apex; spiracular openings horse-shoe shaped, all with their ends directed towards the central scar.

Biology. Larvae were found in tunnels and blotch-shaped cavities in Asphodelus aestivus tubers in November 2005. Under controlled chamber conditions, larvae took 7 to 15 days to pupate and adults emerged after 8 to 11 days.

Material examined. Obtained from larvae found in live Asphodelus aestivus tubers larvae at Puerto Corbata (Sa Calobra), Mallorca Island, Spain by M.A. Marcos-García and G. Rotheray, 4 larvae from which were reared 3 males on 18.23.XI.2005; 3 larvae collected 9.VI.2006 in $U$. maritima bulbs at fresneda de Gargantilla, Cabañeros National Park, Ciudad Real, Spain by A. Ricarte from which 2 males and 1 female emerged between 5.-17.VII.2006.

\subsubsection{Eumerus pusillus Loew, 1848}

Puparium. Dimensions: length: $6.43 \mathrm{~mm}$ (67.33); width: $2.58 \mathrm{~mm}$ (2.38-2.67); head skeleton (Fig. 1b): mandibles heavily sclerotised, $3 \times$ as wide as mandibles of $E$. obliquus; with 4 accessory teeth; thorax: anterior respiratory process $0.1 \mathrm{~mm}$ long by $0.04 \mathrm{~mm}$ width, cylindrical in shape and yellowish-brown in colour; mesothoracic prolegs absent; abdomen: pupal spiracles (Figs. 4a, b) $0.25 \mathrm{~mm}$ long, separated by a 

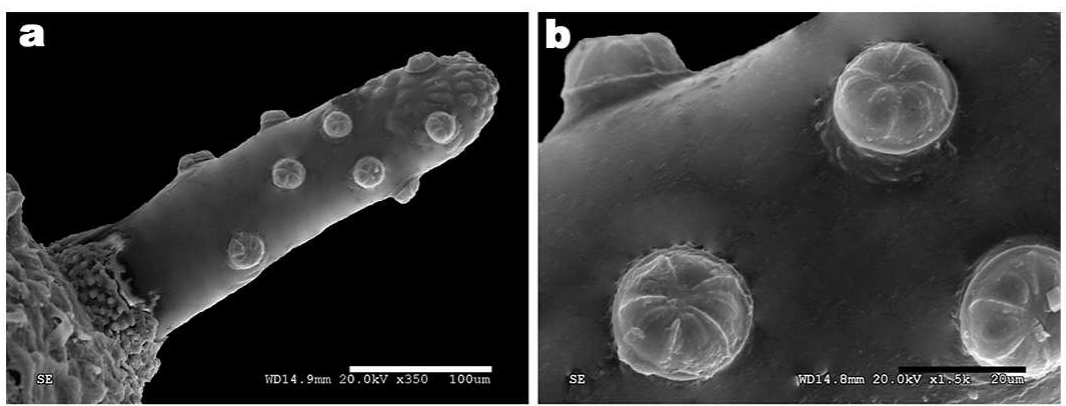

Fig. 4. E. pusillus, SEM "(scale and other photo data are shown at the bottom of each SEM). -a. Pupal spiracle in dorso-lateral view (scale line $=100 \mu \mathrm{m})$.
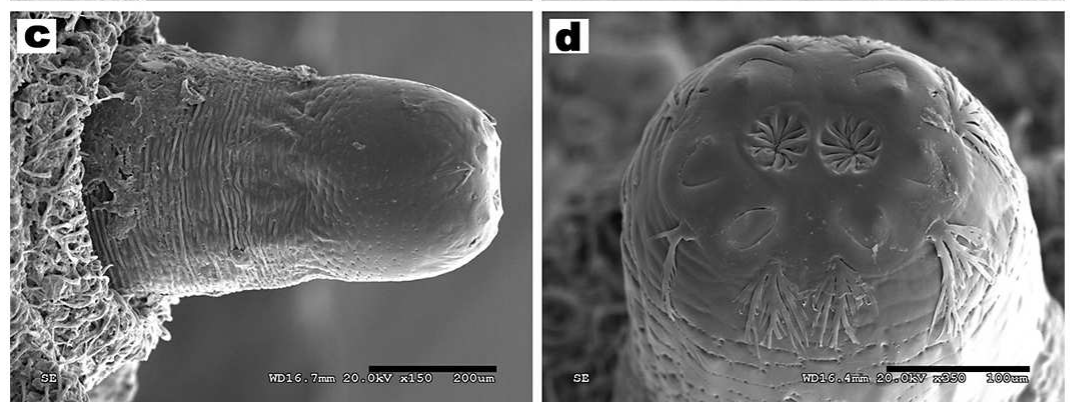
$-b$. Details of spiracular openings on pupal spiracle (scale line $=20 \mu \mathrm{m}) .-\mathrm{c}$. Posterior respiratory processes (prp) in dorsal view (scale line $=200 \mu \mathrm{m}$ ). $-d$. Prp showing the spiracular plate and setae in polar view (scale line $=100 \mu \mathrm{m})$.

distance of $5 \times$ the length, with approximated tubercles at the apex; surface with domed sculpture usually extending no more than a third of the way down the dorsal side and up to two thirds on the ventral side; each tubercle with $4-5$ radially arranged, oval openings, each opening separated by a line; locomotory organs bearing $2-3$ small crochets present on the first 6 abdominal segments; prp (Figs. 4c, d): length: $2.84 \mathrm{~mm}(2.1-3.33)$; $a=$ $0.27 \mathrm{~mm}(0.23-0.31) ; b=0.29 \mathrm{~mm}(0.19-0.35)$; $a / b=0.93(n=9)$; below transverse ridge transversally striated and above ridge finely punctured and smooth at apex; spiracular openings horse-shoe shaped, all with their ends directed towards the central scar.

Biology. Larvae were found in decayed parts of Urginea maritima bulbs in April 2005. Infested bulbs usually contained many larvae. Under controlled chamber conditions, larvae took 38 days to pupate and adults emerged after 19 days.

Material examined. Obtained from larvae found in live Urginea maritima bulbs at La Alcornoquera, Cabañeros National Park, Ciudad Real, Spain by M.A. Marcos-García, A. Ricarte and G. E. Rotheray, 11 larvae, 5.IV.2005 and one puparium from which was reared one male 25.VI.2005.

\subsection{Descriptions of early stages of Merodon}

\subsubsection{Characters shared by early stages of Merodon}

Larvae sub-cylindrical in cross-section, tapered anteriorly, anal segment inclined; head: antennae and maxillary organs on a pair of rounded not cyclindrical projections; dorsal lip smooth, lacking setae; head skeleton: mouth-hooks external to the mouth, heavily sclerotised and mandibular lobes sclerotised and fused with the mandibles; thorax: anterior spiracular process with spiracular openings at the apex of a cyclindrical, sclerotised projection; abdomen: locomotory organs appearing as pairs of raised domes on abdominal segments $1-6$ and lacking a planta and crochets; anal segment retracted and bearing 4 instead of the usual 3 pairs of lappets (fleshy projections on the anal segment bearing sensilla (Rotheray \& Gilbert 1999), the middle pair divided into two approximated lappets; posterior respiratory process (prp) short, not as long as broad, retracted into an integumental pocket; dark brown in colour; spiracular plates with 4 pairs of convoluted spiracular openings. 


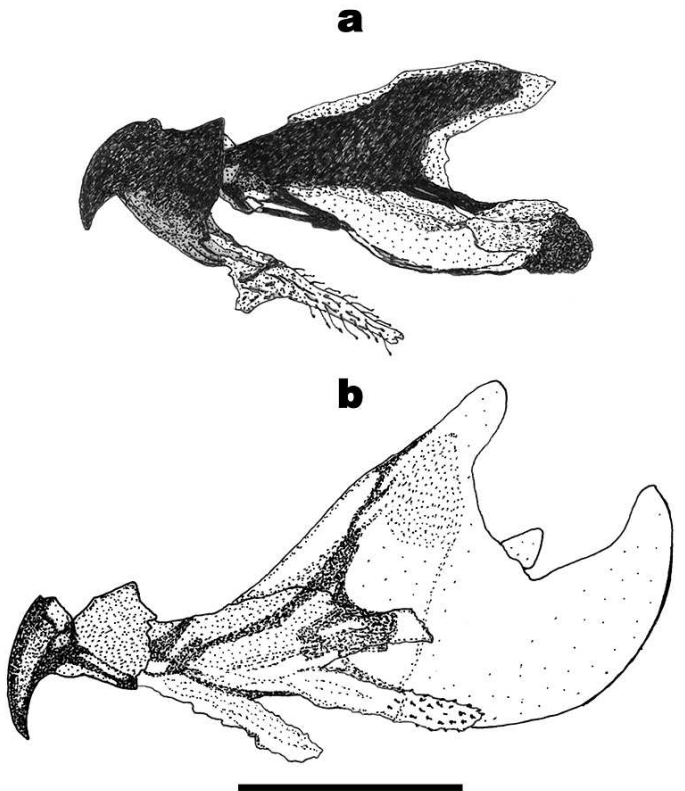

Fig. 5. Head skeletons of Merodon species in lateral view (scale line $=1 \mathrm{~mm}$ ). - a. M. luteihumerus. -b. M. constans.

\subsubsection{Merodon constans (Rossi, 1794)}

Third stage larva. Dimensions: length: mean $19.83 \mathrm{~mm}$ (range 18.5-22.5); width: $7.5 \mathrm{~mm}$ (6.88-8.13); height: $6.05 \mathrm{~mm}(5.63-6.5)(n=5)$; head skeleton (Fig. 5a): mouth-hooks not as extensively sclerotised as $M$. luteihumerus (compare Figs. 5a, b); ventral cornu round in profile view; apical mandibular hooks $0.54 \mathrm{~mm}$ long without accessory teeth and, in apical view, separated at apex by about the same distance as basal width (Figs. 6c, d); thorax: anterior respiratory processes sclerotised, $0.11 \mathrm{~mm}$ long by $0.06 \mathrm{~mm}$ wide, cyclindrical in shape, yellowish-brown in colour, with 2 apical, oval-shaped, spiracular openings; mesothorax and metathorax with groups of conspicuous yellowish-brown spicules on the antero-ventral and lateral margins; abdomen: integumental vestiture comprising backwardly directed broad setae, about as tall as basally broad; anal segment $1.33 \mathrm{~mm}$ long, about half as long as the $6^{\text {th }}$ abdominal segment; first (= anterior) pair of lappets $0.12 \mathrm{~mm}$ long, on fleshy projections; middle lappets consisting of 2 separate, dome-shaped projections bearing sensilla at their apices about the same length as the first lap- a
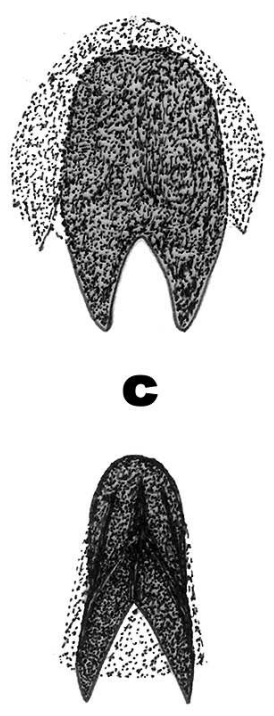

$\mathbf{e}$

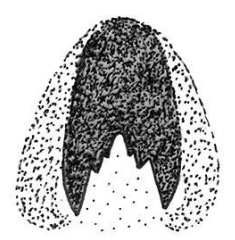

Fig. 6. Mouth-hooks of Merodon species in frontal and lateral views (scale line $=0.6 \mathrm{~mm}$ ). $-\mathrm{a}, \mathrm{b}$. M. luteihumerus. $-\mathrm{c}$, d. $M$. constans. - e, f. $M$. equestris.

pets; third (-posterior) pair of lappets with ventral sensilla bearing a single seta and the apical sensilla with 2-3 surrounding setae; third pair of lappets twice as long as the first pairs of lappets; prp (Fig. 7a): maximum dorso-ventral height at the prp base (c): mean $0.72 \mathrm{~mm}$ (range 0.56$0.81)$, maximum width at the prp base $(d)$ : mean $0.8 \mathrm{~mm}(0.6-0.88) ; c / d=0.9(n=5)$; blackishbrown, shiny, mat, lacking obvious sculpturing, sub-cylindrical in cross section; spiracular plate with 4 pairs of highly convoluted (more than 2 curves) spiracular openings.

Material examined. 2 larvae labelled as Merodon sp. constans Rossi, 39-18852, Morocco, N. Y. 83422, 2.XI.29, C.T.G; 3 larvae labelled as Merodon sp, in cipollini (Muscari 


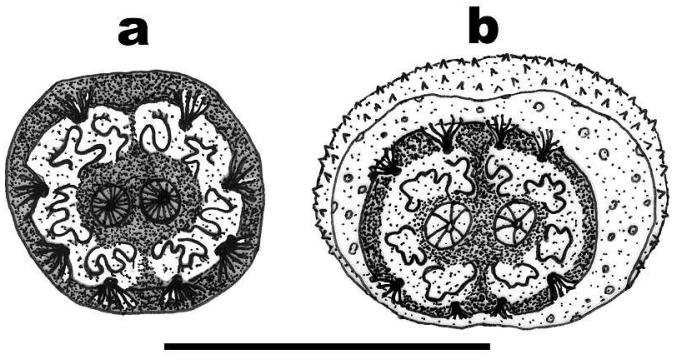

Fig. 7. Posterior respiratory processes of Merodon species showing spiracular plate and setae, in polar view $($ scale line $=1 \mathrm{~mm}) .-$ a. $M$. constans.

-b. M. equestris.

comosum) bulbs from Morocco, intercepted at New York City, 13.XI.1929, NY, No. 13329.

\subsubsection{Merodon luteihumerus Marcos-García, Vujić and Mengual, 2007}

Egg. Length: mean 1.95, range 1.8-2.1 mm; width: $0.74,0.58-0.9 \mathrm{~mm}(n=10)$; glossy white in colour and elongate-oval in shape; chorion with rounded units aligned longitudinally with clear side branches (Fig. 8a).

First larval stage. Length: mean 2.16, range 2.1-2.22 mm; width: $0.59,0.51-0.66(n=2)$; offwhite and truncate at either end; mandibles and prp conspicuous and chestnut-brown in colour, mandibular hook with a ventral accessory tooth; integument with rows of setae long or longer than body height; lappets $2 / 3$ not on distinct projections and appearing as 2 approximated sensilla with associated setae; forth pair of lappets larger than the first 2; ventral surface with prolegs on first 7 abdominal segments, each proleg with 2-3 crochets.

Third larval stage. Dimensions: length: mean $17.66 \mathrm{~mm}$ (range 15-22.88); width: $6.41 \mathrm{~mm}$ (5.75-6.75); height: $5.63 \mathrm{~mm}(5-6.38)(n=4)$; head skeleton (Fig. 5a): mouth-hooks extensively sclerotised and with ventral cornu bar-shaped in profile view; mouthooks $0.56 \mathrm{~mm}$ long without accessory teeth and, in apical view, separated at apex by less distance than basal width (Figs. 3a, b); thorax: anterior respiratory process sclerotised, $0.16 \mathrm{~mm}$ long by $0.14 \mathrm{~mm}$ wide, cylindrical in shape, blackish-brown in colour, with up to 5 oval-shaped, spiracular openings across the apex; mesothoracic prolegs absent; abdomen: integument coriaceous, without setae; anal segment $1.84 \mathrm{~mm}$ long, about 0.6 as long as the $6^{\text {th }}$ abdominal segment; all lappets with basal projection barely produced; middle lappets consisting of 2 separate projections; prp (Fig. 8 b): $c=0.78 \mathrm{~mm}$ $(0.67-0.86) ; d=1.06 \mathrm{~mm}(0.92-1.15) ; c / d=0.74$ $(\mathrm{n}=12)$; black, shiny, with a ridge separating the punctured base below and coriaceous above, sub-
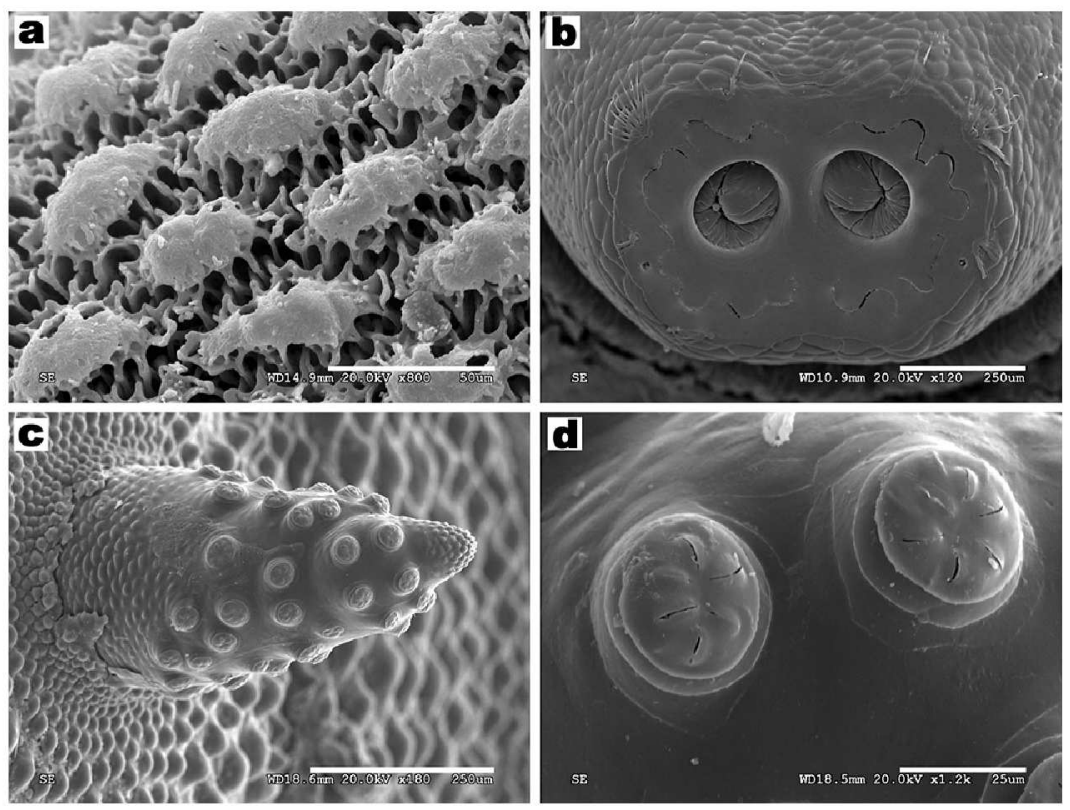

Fig. 8. M. luteihumerus, SEM "(scale and other photo data are shown at the bottom of each SEM). - a. Details of egg sculpture (scale line $=50 \mu \mathrm{m})$. - b. Posterior respiratory processes showing the spiracular plate and setae in polar view (scale line $=250 \mu \mathrm{m}$ ). -c. Pupal spiracle in ventro-lateral view (scale line $=250 \mu \mathrm{m}$ ). $-d$. Details of spiracular openings on pupal spiracle (scale line $=25$ $\mu \mathrm{m})$. 
elliptical in cross section; spiracular plate with 4 pairs of smoothly curved spiracular openings.

Puparium. Shape and dimensions: sub-cylindrical in cross section; anterior extreme rounded, inclined posteriorly and flattened ventrally; dark brown in colour; length:, $12.91 \mathrm{~mm}$ (11.8814.38); width: $6.78 \mathrm{~mm}(6-7.5)$; height: $5.99 \mathrm{~mm}$ $(5.25-6.75)(n=12)$; pupal spiracles (Figs. 8c, d): tapering, $0.5-0.6 \mathrm{~mm}$ long, separated by a distance of $4 \times$ their length; except for coriaceous base and apex, each spiracle bearing numerous, irregularly-spaced, domed tubercles; each tubercle with 4-7 radially arranged spiracular openings; surface smooth between tubercles.

Biology. Both males and females were observed flying near, resting on or feeding at flowers of Urginea maritima plants from the end of August to the end of September in 2004 and 2005 ( $>50$ observations). Up to 3 adults sometimes rested simultaneously on the same flowering stem. Three $M$. luteihumerus females were observed in August 2005 laying eggs on desiccated leaves at the top of bulbs. Females often settled for oviposition in the narrow gap between the bulb and the surrounding soil. During oviposition which only took place at the end of the day, females made an interrupted buzzing sound and remained in position for up to 15 minutes. From February to July 2005, larvae were found excavating tunnels inside $U$. maritima bulbs. Although infested bulbs are large relative to larvae, no more than 3 larvae were found per bulb. Under controlled conditions in rearing chambers, eggs hatched after 5 days, larvae took up to 105 days to pupate and adults emerged 22 to 39 days following pupariation. Eumerus larvae are sometimes present in the tunnels made by $M$. luteihumerus larvae.

Material examined. Obtained from Urginea maritima bulbs at various localities in Cabañeros National Park, Ciudad Real, Spain by A. Ricarte, eggs: Gargantilla valley: 3 collected 26.VIII. 2005 and 7 collected 3.IX.2005, from the tops of $U$. maritima bulbs; first stage larvae: 2 emerged on 8.IX.2005 from eggs collected on 3.IX.2005; third stage larvae: Santiago valley: 2 larvae, 8.IV.2005; La Alcornoquera, 1 larva, 22.V.2005; puparia: La Alcornoquera: 3 puparia from soil surrounding $U$. maritima bulbs, 25.II.-25.III. 2005, 7 larvae from which were reared 2 females and 4 males emerged 19.-29.VII.2005; Santiago valley: 1 puparium on the surface of a bulb, 8.IV.2005; 7 larvae from which were reared $1 \mathrm{fe}-$ male and 6 males emerged 25.VII.-1.VIII.2005.

\section{Discussion}

Among Syrphidae Eumerus and Merodon third stage larvae and puparia are most similar to those of Alipumilio Shannon, 1927, Portevinia Goffe, 1944 and Cheilosia Meigen, 1822 in having a hook at the apex of the mandibles which protrudes from the mouth when the larva is inactive. In other syrphids the mandibles lack an apical mandibular hook and the mandibles do not protrude from the mouth when the larva is inactive (Rotheray \& Gilbert 1999). Third stage larvae and puparia of Alipumilio, Eumerus and Merodon are distinguished from all other syrphid larvae by the possession of 4 pairs of lappets on the anal segment in which the middle pair appears to have divided (Rotheray \& Gilbert 1999). In other syrphid larvae 3 pairs of lappets are present.

Alipumilio can be distinguished from Eumerus and Merodon by the possession of prolegs on of each of the first 7 abdominal segments bearing grouped crochets rather than crochets in rows (Rotheray et al. 2000). Prolegs with crochets are absent in all known Eumerus and Merodon larvae except those of E. obliquus and E. purpurariae Baez, 1982 but these species bear mesothoracic prolegs which are absent in Alipumilio. Third stage larvae and puparia of Eumerus and Merodon can be distinguished from each other by characters of the head and the prp. In Eumerus the mandibular apical hooks are small and only just protrude from the mouth. The mandibular lobes which laterally connect the mandibular sclerite with the membranous head are fleshy. The dorsal lip is coated in rows of setae. In Merodon, the mandibular apical hooks are large and protrude conspicuously from the mouth. The mandibular lobes are sclerotised and support the mandibular sclerite and the dorsal lip is smooth and lacks setae. In Eumerus the anal segment and the prp are relatively elongate, longer than broad and, in an inactive larva, the base of the prp is hidden completely within a deep fold of the anal segment. In contrast the anal segment and the prp in 
Merodon are short, as long as broad or broader. The anal segment is inclined dorsally and the base of the prp is visible being only within a shallow fold of the anal segment.

$M$. constans can be separated from $M$. luteihumerus by numerous characters. The mouthhooks are separated at the apex by a distance wider than their basal width in $M$. constans and by less distance than basal width in $M$. luteihumerus. The integument of $M$. constans is coated with setae but that of $M$. luteihumerus is coriaceous and lacks setae. The anterior spiracles of $M$. constans have a pair of openings but those of $M$. luteihumerus have 4-5 openings. The first and third pairs of lappets of $M$. constans are well developed but those of $M$. luteihumerus are barely produced. The mean height of the prp as a proportion of the mean width in $M$. constans is 0.9 and less (0.74) in $M$. luteihumerus. The spiracular openings of the prp in $M$. constans and M. equestris (Fabricius, 1794) (Figs. 7a, b) are highly convoluted but gently curved in $M$. luteihumerus. The larva of $M$. equestris differs from both these species in having accessory hooks in addition to the main mouthook (Figs. 6e, f).

E. pulchellus and E. pusillus are more similar to each other than E. obliquus. E. obliquus is similar to E. purpurariae and both are easily distinguished from the first two species by the possession of prolegs with crochets on the mesothorax and first 7 abdominal segments. E. obliquus is distinguished from $E$. purpurariae by a shorter prp, about $2.5 \times$ as long as basally broad and conspicuous vestiture. In E. purpurariae the prp is $4 \times$ as long as basally broad and vestiture is short and inconspicuous. A single accessory tooth to the mouthooks, pupal spiracles separated by $4 \times$ their length and the base of the prp with spicules separates E. pulchellus from E. pusillus. In E. pusillus there are 4 accessory teeth, the pupal spiracles are separated by $5 \times$ their length and the base of the prp lacks spicules. In summary, it's relatively easy to separate Eumerus species by early stages in contrast with the difficulties sometimes found in adult determination. This encourages to do field work orientated to explore the breeding sites of the high number of Eumerus species with unknown immature stages, which may contribute to clarify the taxonomy of the genus and some species in particular.
Eumerus and Merodon species have been reared from a range of plants (Table 1) and the rearings presented here from Asphodelus and Urginea extend the known range of foodplants within these genera. E. obliquus represents the third Palaeartic syrphid species found breeding in decaying $O$. maxima in the Mediterranean region (Pérez-Bañón \& Marcos-García 1998). Opuntia cacti were introduced into Europe in the $16^{\text {th }}$ century from Mexico and certain species became serious agricultural pests in several Mediterranean countries (Dodd 1940). Obviously, the three syrphid species must develop in other situations too.

In bulbs of $U$. maritima the feeding modes of Eumerus and Merodon appear to differ. In situ Eumerus larvae were often partially or wholly submerged in brown discoloured oily material that appeared to result from decay of bulb tissues. In contrast, Merodon larvae were rarely submerged in such material and their tunnels were clean and white being apparently clear of such decay. In Asphodelus and U. maritima we observed that E. pulchellus larvae were similarly associated with brown, decayed tissue. Creager and Spruijt (1935) have shown that optimum development in Eumerus larvae depends on the presence of decay organisms. A symbiotic relationship may exist between them with Eumerus larvae rasping and scraping and hence exposing fresh plant tissues for these organisms to develop on and from which decay products, the larvae themselves develop. Eumerus larvae are probably more saprophagous than phytophagous. In contrast, Merodon larvae are probably more phytophagous. However in the UK, we have seen Merodon infested Narcissus bulbs full of brown oily material. These bulbs had overwintered and it is possible that larvae had finished developing on fresh tissues earlier but had not yet left the bulbs even though they were filling with wet decay.

The smaller mouthooks, fleshy mandibular lobes, setalose dorsal lip and presence of ventral pharyngeal ridges of Eumerus larvae appear to facilitate this type of development. The mouthhooks at the apex of the mandibules rasp and scrape plant tissues and the fleshy mouthparts scoop up the oily decayed material. The larger more heavily sclerotised mandibles and absence 
Table 1. Published foodplants of Eumerus and Merodon and early stage data.

Species Foodplants and early stage data

E. amoenus Loew, 1848

E. compertus Villeneuve, 1924

E. obliquus (Fabricius, 1805)

E. purpurariae Baez, 1982

E. strigatus (Fallen, 1817)

E. tricolor (Fabricius, 1798)

E. tuberculatus Rondani, 1857

M. avidus Rossi, 1790

M. bombiformis Hull, 1944

M. eques (Fabricius, 1805)

M. equestris (Fabricius, 1794)

M. nigritarsis Rondani, 1845
Reared from Allium (Alliaceae), potato tubers, water melon, grapes, rotten paw-paw and damaged rhizomes of Iris germanica (Iridaceae) (Efflatoun 1922); injurious to onion (Assem \& Nasr 1967); larva not described Reared from bulbs of Cistanche violacea (Orobanchaceae); larva and puparium described (Waitzbauer 1976)

Reared from a wide range of decaying plants including cut flowers in water and fruits and vegetables (de Moor 1973); generalised larval description (de Moor 1973) Reared from Opuntia maxima platyclades (Cactaceae); egg, larva and puparium described (Pérez-Bañón \& Marcos-García 1998)

Reared from Narcissus (Amaryllidaceae) and related plants in commercial situations (Hodson 1927); larva described (Heiss 1938) and compared with $E$. tuberculatus (Hodson 1932a)

Reared from Tragopogon porrifolius L (Asteraceae)

(Arzone 1972); larva not described

Reared from Narcissus and related plants in commercial situations (Hodson 1927); larva compared with Syritta pipiens (Hodson 1931) and E. strigatus (Hodson 1932a) Oviposition in Muscari sp. (Hyacinthaceae) (Reemer \& Goudsmits 2004); larva not described

Reared from Gladiolus sp.; larva and puparium described (Stuckenberg 1956)

Reared from Narcissus sp.; larva not described (Pehlivan \& Akbulut 1991)

Reared from Iris, Narcissus and related plants in commercial situations; egg, larva (all instars) and puparium described; life cycle described (Hodson 1932b); unusual rearing record from Hippeastrum sp.

(Amaryllidaceae) (Wallace \& Wallace 1990); head skeleton described and figured (Hartley 1961) Reared from Hyacinthaella pallasiana (Ster.) Losinsk. (Hyacinthaceae) (Stepanenko \& Popov 1997); larva not described of ventral pharyngeal ridges that characterise the mouthparts of Merodon larvae are probably better suited to fragmenting bulb tissues into small pieces and imbibing them directly. Furthermore, the retracted and inclined anal segment bearing a short prp that is also characteristic of Merodon larvae is similarly found in many Cheilosia, Portevinia and Temnostoma larvae that tunnel through plant tissues. Such features probably protect the spiracular openings from becoming blocked (Rotheray \& Gilbert 1999). These feeding mode differences could be sufficient to explain the co-occurrence of Eumerus and Merodon larvae in the same bulb, as was frequently observed between E. pusillus and $M$. luteihumerus in U. maritima. However detailed study of possible interactions has not been made (Marcos-García \& Ricarte in prep.).

It is possible that coevolution has developed between $U$. maritima and E. pusillus and $M$. luteihumerus. In the late summer when few other plants than U. maritima, are flowering, adults of these syrphids may depend on them for pollen and nectar and co-incidentally pollinate them. Despite their toxicity (Blondel \& Aronson 1999), the bulbs are also used for breeding. 
The plant may have responded to the need to attract such pollinators by developing large bulbs which are able to tolerate larval feeding and large bulbs may also act as an additional attractant to ovipositing females. Furthermore, U. maritima plants often grew in clumps at Cabañeros with several approximated bulbs. The bulbs of many Amaryllidaceae and Hyacinthaceae are well known to split and divide during growth and it is possible that this feature is also involved as part of a co-evolved response which probably increases attractiveness to their pollinators.

Furthermore, other features suggest a close relationship between $M$. luteihumerus and $U$. maritima: the specificity of the fly for using bulbs of only this plant for breeding; the absence of other Merodon species breeding in the bulbs; the large sizes of the larvae and bulbs; the synchrony between the activity period of the adults and the flowering time of the plant; the dense pilosity, size and other adult features including flower visiting behaviour typical of insects specialised for pollination and, the constant spatial coincidence between both species in the study area. There is a spatial co-incidence between both species (PérezChiscano 1996, Marcos-García et al. 2007) but the plant is much more widespread and common than $M$. luteihumerus what suggests an apparent not coincidence outside the study area probably due to the lack of samples. More detailed studies of the relationship are required to understand the requirements of $M$. luteihumerus for conservation.

A shift appears to have taken place in $E$. obliquus and E. purpurariae. These species breed in already decayed material, probably of various kinds at or near ground level rather than in underground bulbs and tubers (Table 1). They probably do not have symbiotic relationships with decomposer organisms. Nor are they specialised for particular plants or part of co-evolved systems. Morphologically their larvae have smaller and less sclerotised mandibles and probably do not rasp and scrape live plant tissues but more simply imbibe already decayed material. They also have relatively long anal segments and prps which probably enable them to respire in larger quantities of liquid decay than found in bulbs and tubers. They also possess unique character states among Eumerus larvae of prolegs with crochets on the mesothorax and first seven abdominal segments and the orientation of crochets on each proleg is strictly transverse. No other syrphid larvae are known with such features suggesting that these have developed independently. Although only two Eumerus species are known to have apparently undergone such a shift in breeding site and associated morphological changes, others probably exist and they may constitute a species group or highly derived taxa within Eumerus.

Acknowledgements. We thank Chris Thompson for arranging loans of material from the Smithsonian Institution, USA. Thanks to I. Torregrosa and Z. Nedeljković for helping in the field work and to the Dr. S. Ríos for plant identification. We are very grateful to the director and staff of the Cabañeros National Park. Financial support was provided by the Spanish Ministerio de Medio Ambiente (040/2002), Generalitat Valenciana (GV04A-576), Spanish Ministerio de Educación y Ciencia (projects CGL2005-07213/BOS and CGL2006-13847-C02-01/BOS).

\section{References}

Arzone, A. 1972: Reperti biologici su Eumerus tricolor Meigen, nocivo alle coltivazioni di Tragopogon porrifolius L. in Piemonte (Dipt. Syrphidae). - Annali Fac. Sci. Agr. Univ. Torino 7: 17-52.

Assem M. A. \& Nasr E. S. A. 1967: A syrphid fly, Eumerus amoenus Loew injurious to onion in U.A.R. (Diptera: Syrphidae). - Agric. Res. Rev. (Cairo) 45 (2): 27-32.

Assem, M. A., Abdel, A. M. \& Yousef, K. E. H. 1972: Efficiency of insecticidal dusts in controlling the bulb fly, Eumerus amoenus Loew on stored onion bulbs. Bull. Entomol. Soc. Egypt (Economic Series) 6: 217 219.

Blondel, J. \& Aronson, J. 1999: Biology and wildlife of the Mediterranean region. Oxford University Press, Oxford (UK). $328 \mathrm{pp}$.

Chandler, A. E. F. 1968: A preliminary key to the eggs of some of the commoner aphidophagous Syrphidae (Diptera) occurring in Britain. - Trans. R. Entomol. Soc. London 120: 199-217.

Conijn, C. G. M. 1990: Control of the large narcissus fly, Merodon equestris Fab. (Diptera: Syrphidae) in the field. - Med. Fac. Landbouww. Rijksuniv. Gent 55 (2b): 675-679.

Creager, D. B. \& Spruijt, F. J. 1935: The relation of certain fungi to larval development of Eumerus tuberculatus Rond. - Ann. Entomol. Soc. Am. 28: 425-437.

Dodd, A. P. 1940: The Biological Campaign Against Prickly-Pear. - Commonwealth Prickly-Pear Board, Brisbane.

Efflatoun, H. C. 1922: A monograph of Egyptian Diptera, Pt.1: Syrphidae. - Mem. Egypt. Entomol. Soc. 2(1): 1-123. 
Farràs, A. 1988: Les liliates o angiospermes monocotiledònies. - In: Masalles, R.M. et al. (eds), Història Natural dels Països Catalans, Plantes Superiors: 6: 317-376. Enciclopèdia Catalana S.A., Barcelona. 463 pp.

Hartley, J. C. 1961: A taxonomic account of the larvae of some British Syrphidae. - Proc. Zool. Soc. London 136: 505-573.

Hartley, J. C. 1963: The cephalopharyngeal apparatus of syrphid larvae and its relationship to other diptera. Proc. Zool. Soc. London 141: 261-280.

Heiss, E. M. 1938: A classification of the larvae and puparia of the Syrphidae of Illinois exclusive of Aquatic Forms. - Ill. Biol. Monogr. 16 (4), pp 142, 17 pls.

Hodson, W. E. H. 1927: The bionomics of the lesser bulb flies, Eumerus strigatus, Flyn., and Eumerus tuberculatus, Rond., in South-West England.-Bull. Entomol. Res. 23: $429-448$.

Hodson, W. E. H. 1931: A comparision of the immature stages of Eumerus tuberculatus Rond. and Syritta pipiens Lin. (Syrphidae). — Bull. Entomol. Res. 22: 5558 .

Hodson, W. E. H. 1932a: A comparison of the larvae of Eumerus strigatus, Flyn., and Eumerus tuberculatus, Rond. (Syrphidae). — Bull. Entomol. Res. 23: 247249.

Hodson, W. E. H. 1932b: The large narcissus fly, Merodon equestris, Fab. (Srphidae). - Bull. Entomol. Res. 17: 373-385.

Marcos-García, M. A., Vujić, A. \& Mengual, X. 2007: Revision of Iberian species of the genus Merodon (Diptera: Syrphidae). — Eur. J. Entomol. 104: 531572.

de Moor, F. C. 1973: Notes on a syrphid fly, Eumerus obliquus (Fabricius) (Diptera: Syrphidae). - Arnoldia 6 (15): $1-7$.

Peck, L. V. 1988: Syrphidae. — In: Soos, A. \& Papp, L. (eds), Catalogue of Palaearctic Diptera, 8: 11-230. Akad. Kiado, Budapest.

Pehlivan, E. \& Akbulut, N. 1991: Some investigations on the syrphid species attacking on Narcissus in Karaburun (Izmir) and the biology and control measures of Merodon eques (F.) (Diptera). - Doğa - Tr. J. of Agriculture and Forestry 15: 47-81.

Pérez-Bañón, C. \& Marcos-García, M. A. 1998: Life history and description of the immature stages of Eumerus purpurariae (Diptera: Syrphidae) devoloping in Opuntia maxima. - Eur. J. Entomol. 95: 373-380.

Pérez-Chiscano, J. L. 1996: Aportaciones al conocimiento de Urginea maritima (L.) Baker (Liliaceae). - An. Jard. Bot. Madr. 54: 392-398.

Reemer, M. \& Goudsmits, K. 2004: Oviposition observed in Chrysotoxum cautum, C. vernale and Merodon avidus (Diptera: Syrphidae). — Volucella 7: 217-218.

Roberts, M. J. 1969: The Structures of the Mouthparts of Syrphid larvae (Diptera) in Relation to Feeding Habits. - Acta Zool. 51: 43-65.

Rotheray, G. E. 1993: Colour Guide to Hoverfly larvae (Diptera: Syrphidae). — Dipterists Digest No. 9. Sheffield. $156 \mathrm{pp}$.

Rotheray, G. E. \& Gilbert, F. 1999: Phylogeny of Paleartic Syrphidae (Diptera): evidence from larval stages. Zool. J. Linn. Soc. 127: 1-112.

Rotheray, G. E., Marcos-García, M. A., Hancock, E. G. \& Gilbert, F. S. 2000: The systematic position of Alipumilio and Nausigaster based on early stages (Diptera, Syrphidae). - Studia Dipterologica 7: 133-144.

Sack, P. 1932: Syrphidae. — In: Linder, E. (ed.), Die Fliegen der Palaerktischen Region, Stuttgart, 4 (4): 1-451.

Speight, M. C. D. 2006: Species accounts of European Syrphidae (Diptera), Ferrara 2006. — In: Speight, M. C. D., Castella, E., Sarthou, J.-P. \& Monteil, C. (eds), Syrph the Net, the database of European Syrphidae, vol. 54, 252 pp., Syrph the Net publications, Dublin.

Stepanenko, O. V. \& Popov, G. V. 1997: On the immature stages biology of Merodon nigritarsis Rondani, 1845 (Diptera: Syrphidae). The Karkov Ent. Soc. Gazette 5 (2): $40-43$.

Stuckenberg, B. R. 1956: The immature stages of Merodon bombiformis Hull, a potencial pest of bulbs in South Africa. - J. Entomol. Soc. South Afr. 19 (2): 219 224.

Thompson, F. C. (ed.) 2006: Merodon (Merodon) constans (Rossi, 1794). Biosystematic Database of World Diptera, Version 7.5. 1 work records (not peer-reviewed material). [www document] URL http://www. diptera.org/biosys.htm (accessed on 13 Jun. 2007).

Vujić, A. \& Šimić, S. 1999: Genus Eumerus Meigen 1822 (Diptera: Syrphidae) in the area of the former Jugoslavia. - Glasnik Prirod Muzeja u Beogradu B 49-50 (1995-1998), 173-190.

Waitzbauer, W. 1976: Eumerus compertus Villeneuve (Dipt., Syrphidae); larve und puparium. - Zool. Anz. 196: 16-22.

Wallace, B. \& Wallace I. D. 1990: An unexpected rearing record for Merodon equestris. - Hoverfly Newsletter. No.11, 8. 